B I O S C I E N C E

J O U R N A L

\section{SERUM BIOCHEMICAL REFERENCE RANGES FOR PREGNANT SHEEP}

Laura Ferrari Monteiro VARANIS $^{1}$ (D), Karla Alves OLIVEIRA ${ }^{2}$ (D) Carolina Moreira ARAÚJO $^{1}$ (D), Wendell Fernando Guimarães da CRUZ ${ }^{3}$ (D) , Gilberto de Lima MACEDO JÚNIOR ${ }^{4}$ iD

\footnotetext{
${ }^{1}$ Postgraduate program in Animal Science, Federal University of Uberlândia, Uberlândia, Minas Gerais, Brazil.

2 Postgraduate program in Animal Science, Paulista State University, Jaboticabal, São Paulo, Brazil.

3 Postgraduate program in Animal Science, Federal University of Lavras, Lavras, Minas Gerais, Brazil.

${ }^{4}$ Department of Veterinary Science, Federal University of Uberlândia, Uberlândia, Minas Gerais, Brazil.
}

Corresponding author:

Wendell Fernando Guimarães da Cruz

Email: wendell_fg@hotmail.com

How to cite: VARANIS, L.F.M., et al. Serum biochemical reference ranges for pregnant sheep. Bioscience Journal. 2021, 37, e37036. https://doi.org/10.14393/BJ-v37n0a2021-47695

\begin{abstract}
Late pregnancy is accompanied by dramatic changes in the metabolism of sheep, in which the nutrient requirements increase and the metabolic capacity of ewes is under severe stress due to the rapid foetal growth and development of the mammary gland. The blood metabolic profile can be used to monitor these alterations, which can lead to metabolic disorders such as pregnancy toxaemia. However, data available on serum parameters in sheep do not consider physiological state. Therefore, the present study aimed to determine the biochemical reference ranges for pregnant ewes, including serum energy, protein and enzyme-related metabolites. Data from a variety of metabolites were obtained from experiments performed in several institutions and commercial farms using Santa Inês, Dorper, Lacaune, Morada Nova, Bergamacia and Suffolk ewes reared under different conditions (grazing, feedlot, semi-feedlot, collective and/or individual pens, and metabolic cages) from 2006 to 2017. All animals were healthy and without feed restriction. Data from ewes with any clinical manifestations were removed. The metabolic energy profile included data of glucose, cholesterol, triglyceride, high-density lipoprotein, low-density lipoprotein and verylow-density lipoprotein levels; the metabolic protein profile included the metabolites total protein, uric acid, urea, albumin, and creatinine; and the metabolic enzymatic profile included the enzymes aspartate aminotransferase, gamma-glutamyl transferase and alkaline phosphatase. The reference ranges were estimated using the software RefVal 4.11. Dixon's test was used to identify and remove outliers. The confidence intervals and percentiles were estimated using the nonparametric method of bootstrap when data were not normally distributed. A 95\% confidence level was used. The serum biochemical reference ranges for pregnant sheep determined in our study were strongly divergent from those established by one of the most cited books on the topic, especially considering the high serum urea and cholesterol concentrations and low levels of blood glucose observed. Therefore, it is essential to consider physiological status when evaluating the blood metabolic profile of pregnant ewes in order to maintain an adequate nutritional management and to prevent health disorders that may lead to productive and reproductive losses.
\end{abstract}

Keywords: Ewes. Metabolic Energy Profile. Metabolites. Ovis aries. 


\section{Introduction}

Pregnancy is a physiological state accompanied by dramatic changes in the metabolism of sheep to ensure the successful maintenance of gestation and fetal growth and development (Kandiel, El-Khaiat and Mahmoud 2016). As gestation progresses, the nutrient requirements increase and the metabolic capacity of ewes is under severe stress due to the rapid fetal growth and the development of the mammary gland (Gurgoze et al. 2009), since approximately $80 \%$ of the development of the conceptus takes place in the last six weeks of pregnancy (Rook 2000).

It is known that the energy needs of the fetal-placental unit are primarily met by maternal glucose and lactate (Kaneko, Harvey and Bruss 2008), whereas maternal tissues tend to use lipid sources for energy metabolism aiming at facilitating glucose availability to the fetus through increased gluconeogenesis (Bell 1995). The combination of increased energy demands, inadequate energy intake and metabolic alterations related to high lipid mobilization during late pregnancy results in a condition of negative energy balance in sheep, which could progress into a severe metabolic disorder named pregnancy toxemia (Van Saun 2000; Dzadzowski et al. 2015).Therefore, with the advancement of pregnancy in ruminants, those changes in maternal metabolism to meet fetal nutrient demands might also have an influence on serum biochemistry values (Mohammadi, Anassori and Jafari 2016), which can be used to assess the nutritional status and individual health disorders in livestock (Van Saun 2000). In addition to the physiological status, many aspects, such as breed, sex, age, underfeeding and health might influence the blood metabolic profile in sheep (Yokus et al. 2006).

The analysis of serum biochemistry parameters is a low-invasive and inexpensive alternative for the diagnosis, treatment, and prediction of diseases such as pregnancy toxemia (Bobe, Young and Beitz 2004). Consequently, the identification of changes in the metabolism of sheep through the evaluation of the blood metabolic profile during pregnancy is a useful tool for the management and nutritional decision-making in sheep (Balikci, Yildiz and Gürdoğan 2007; Swetha et al. 2018).

In the literature, the blood metabolic profile does not take into account this physiological status in sheep, which can lead to errors in the diagnosis of diseases and the nutritional management of the flock. So, the hypothesis would be that the reference values found for the pregnant category in animals raised in Brazil would be different from those found in the international literature. Therefore, the present study aimed to determine and compare the serum biochemical reference ranges for pregnant sheep in Brazil.

\section{Material and Methods}

Data from a variety of metabolites were obtained from experiments performed in several institutions (Federal University of Uberlândia, Federal University of Minas Gerais, Federal University of Lavras, Federal Rural University of Rio de Janeiro, Federal University of Tocantins) and commercial farms using Santa Inês, Dorper, Lacaune, Morada Nova, Bergamacia and Suffolk ewes reared under different conditions (grazing, feedlot, semi-feedlot, collective and/or individual pens, and metabolic cages) from 2006 to 2017. Table 1 shows the different types of food used in feeding the animals whose data were used in this study.

Table 1. Main foods used in animal production systems.

\begin{tabular}{cccc}
\hline Energy concentrate & Protein concentrate & Forages and silages & Additive \\
\hline Corn bran & Soybean meal & Braquiaria brizantha & Monensin \\
Citrus pulp & Urea & Braquiaria decumbens & Mineral salt (sheep) \\
Babassu starch flour & Soy cone & Cynodon spp. (hay) & Exogenous enzymes \\
Soy molasses & Babassu flour & Panicum maximum cv. Tanzânia & Yeasts \\
Corn grain & Cottonseed & Panicum maximum cv. Aruana & Virginamycin \\
Propylene glycol & Soybean grain & Panicum maximum cv. Massai & \\
Glycerol & Protected urea & Corn silage & \\
Cookie flour & Dairy substitute & Sorghum silage & \\
& & Tanzânia grass silage & \\
\hline
\end{tabular}


All animals were healthy and without feed restriction. Data from ewes with any clinical manifestations were removed. Data were obtained considering the physiological status of pregnancy regardless of parity, birth type or days of gestation. The metabolic energy profile included data from glucose, cholesterol, triglycerides, HDL (high-density lipoprotein), LDL (low-density lipoprotein) and VLDL (very-lowdensity lipoprotein); the metabolic protein profile encompassed the metabolites total protein, uric acid, urea, albumin, and creatinine; the metabolic enzymatic profile included the enzymes AST (aspartate aminotransferase), GGT (gamma-glutamyl transferase) and ALP (alkaline phosphatase). The analyses were performed on Bioplus 2000 and PKL-125 devices (MH-Lab) using different brands of test kits (Labtest Diagnóstica S. A., GT Group (C and Biotécnica (C). The VLDL and LDL values were obtained using the equations proposed by Friedewald et al. (1972) based on the total serum cholesterol, HDL, and triglycerides:

$$
\begin{gathered}
\mathrm{VLDL}=\mathrm{TG} / 5 \\
\mathrm{LDL}=\mathrm{TC}-\mathrm{HDL}-\mathrm{VLDL}
\end{gathered}
$$

Where $V L D L=$ very-low-density lipoprotein; $T G$ = triglycerides; $L D L=$ low-density lipoprotein; $T C=$ total cholesterol; $\mathrm{HDL}=$ high-density lipoprotein.

Reference intervals were estimated using the software RefVal 4.11 (Solberg 2006). Dixon's test was used to identify and remove outliers. The confidence intervals and percentiles were estimated using the nonparametric bootstrap method when data were not normally distributed. A $95 \%$ confidence level was used.

The physiological reference ranges determined in the present study were compared with established reference intervals for serum biochemical parameters presented by Kaneko, Harvey and Bruss (2008), which is one of the most cited books with about 2800 citations.

\section{Results}

Data relative to the physiological reference ranges for energy, protein and enzyme-related metabolites in pregnant sheep, the sample size and the reference ranges for comparison are shown in table 2.

Table 2. Serum biochemical reference ranges for pregnant ewes, including energy, protein and enzyme-

\begin{tabular}{|c|c|c|c|c|}
\hline Metabolites & Unit & $\mathrm{SS}^{1}$ & Reference ranges (our study) & $\begin{array}{c}\text { Reference ranges (Kaneko, } \\
\text { Harvey \& Bruss 2008) }\end{array}$ \\
\hline \multicolumn{5}{|c|}{ Energy-related metabolites } \\
\hline Glucose & $\mathrm{mg} / \mathrm{dL}$ & 93 & $29-59 *$ & $50-80$ \\
\hline Cholesterol & $\mathrm{mg} / \mathrm{dL}$ & 273 & $13-117$ & $52-76$ \\
\hline Triglycerides & $\mathrm{mg} / \mathrm{dL}$ & 305 & $9-47$ & $9-30$ \\
\hline $\mathrm{HDL}^{2}$ & $\mathrm{mg} / \mathrm{dL}$ & 224 & $7-42 *$ & $N D^{5}$ \\
\hline $\mathrm{LDL}^{3}$ & $\mathrm{mg} / \mathrm{dL}$ & 309 & $4.3-95.5^{*}$ & $N^{5}$ \\
\hline $\operatorname{VLDL}^{4}$ & $\mathrm{mg} / \mathrm{dL}$ & 358 & $1.6-9.8$ & $N^{5}$ \\
\hline \multicolumn{5}{|c|}{ Protein-related metabolites } \\
\hline Total protein & $\mathrm{g} / \mathrm{dL}$ & 308 & $2.26-7.18$ & $6-7.9$ \\
\hline Uric acid & $\mathrm{mg} / \mathrm{dL}$ & 309 & $0.1-0.9$ & $0-1.9$ \\
\hline Urea & $\mathrm{mg} / \mathrm{dL}$ & 300 & $7-55.8$ & $51-128$ \\
\hline Albumin & $\mathrm{g} / \mathrm{dL}$ & 307 & $1.56-5.01 *$ & $2.4-3.0$ \\
\hline Creatinine & $\mathrm{mg} / \mathrm{dL}$ & 299 & $0.2-1.5$ & $1.2-1.9$ \\
\hline \multicolumn{5}{|c|}{ Enzyme-related metabolites } \\
\hline $\mathrm{AST}^{6}$ & $U / L$ & 223 & $45-251^{*}$ & $60-280$ \\
\hline $\mathrm{GGT}^{7}$ & $U / L$ & 220 & $28-104 *$ & $20-52$ \\
\hline$A L P^{8}$ & $\mathrm{U} / \mathrm{L}$ & 233 & $33-331$ & $68-387$ \\
\hline
\end{tabular}
related metabolites.

${ }^{1} \mathrm{SS}$ - Sample size; ${ }^{2} \mathrm{HDL}$ - high-density lipoprotein; ${ }^{3} \mathrm{LDL}$ - low-density lipoprotein; ${ }^{4} \mathrm{VLDL}$ - very-low-density lipoprotein; ${ }^{5} \mathrm{Not}$ determined, ${ }^{6} \mathrm{AST}$ - aspartate aminotransferase; ${ }^{7} \mathrm{GGT}$ - gamma-glutamyl transferase; ${ }^{8} \mathrm{ALP}$ - Alkaline phosphatase. ${ }^{*}$ Parametric data. 
The reference interval for serum glucose (29-59 mg/dL) was lower than that established by Kaneko, Harvey and Bruss (2008), even though the sample size was lower compared to those of the other variables. Reference intervals for serum cholesterol (13-117 mg/dL) were wider than those established by Kaneko, Harvey and Bruss (2008).

The reference interval for serum triglycerides $(9-47 \mathrm{mg} / \mathrm{dL}$ ) was similar to that established by Kaneko, Harvey and Bruss (2008). Reference intervals for serum HDL (7-42 mg/dL), LDL (4.3-95.5 mg/dL) and VLDL (1.6-9.8 $\mathrm{mg} / \mathrm{dL}$ ) were established in this study for pregnant sheep but were not determined by Kaneko, Harvey and Bruss (2008).

The interval for serum total protein $(2.26-7.18 \mathrm{~g} / \mathrm{dL})$ was more extensive than that established by Kaneko, Harvey and Bruss (2008), with a lower reference limit 37.6\% lower than that reported by them. On the other hand, the reference interval for serum uric acid $(0.1-0.9 \mathrm{mg} / \mathrm{dL}$ ) was narrow, since Kaneko, Harvey and Bruss (2008) established an upper reference limit 47.3\% higher than that observed in the present study.

The reference interval for serum urea $(7-55.8 \mathrm{mg} / \mathrm{dL})$ was slightly lower than the reference interval established by Kaneko, Harvey and Bruss (2008). The intervals for serum albumin (1.56-5.01 g/dL) were similar than the reference intervals established by Kaneko, Harvey and Bruss (2008), the minimum reference value being $35 \%$ lower and the maximum reference value for pregnant sheep $67 \%$ higher. Reference intervals for serum creatinine $(0.2-1.5 \mathrm{mg} / \mathrm{dL}$ ) included as the lower limit a minimum value $83 \%$ lower than that established by Kaneko, Harvey and Bruss (2008).

Intervals for serum AST (45-251 U/L) included as the minimum reference a value $25 \%$ lower than that established by Kaneko, Harvey and Bruss (2008), whereas reference intervals for GGT (28-104 U/L) included as the maximum reference a value $100 \%$ higher than the upper limit defined by Kaneko, Harvey and Bruss (2008). The reference interval for serum ALP (33-331 U/L) included as the lower limit a minimum value 38\% lower than that established by Kaneko, Harvey and Bruss (2008).

\section{Discussion}

Glucose is the primary metabolic fuel used by the sheep fetus (Haffaf and Benallou 2016), even though it is not a sensitive parameter of energy status since glucose homeostasis is subject to tight control (Kaneko, Harvey and Bruss 2008). The greater fetal demand in pregnant ewes is not accompanied by increased endogenous glucose production, resulting in lower glucose levels during pregnancy (Raoofi et al. 2013). In addition to the increased maternal glucose diffusion and use to supply the fetal demand (Deghnouche et al. 2013), the lower plasma glucose levels in pregnant sheep are also attributed to impaired gluconeogenesis by the liver from glucogenic precursors such as propionate, which is derived from rumen fermentation (Dzadzowski et al. 2015). In an assay with 110-day pregnant Border Leicester x Romney ewes carrying multiple pregnancies, Hu et al. (1990) reported values of blood glucose reaching $29.9 \mathrm{mg} / \mathrm{dL}$. According to Safsaf et al. (2014), blood glucose levels in multiparous Ouled Djellal ewes reached $34.6 \mathrm{mg} / \mathrm{dL}$ after 15 weeks of pregnancy, whereas Castillo et al. (1999) observed mean blood glucose levels of 34.52 $\mathrm{mg} / \mathrm{dL}$ in Assaf ewes under an intensive management system at the 90th day of pregnancy. A study conducted by Haffaf and Benallou (2016) using pregnant ewes reported blood glucose levels of 46, 41 and $39 \mathrm{mg} / \mathrm{dL}$ for the periods of 61-90, 91-120 and 121-145 days of pregnancy, respectively. Therefore, with advancing pregnancy, blood glucose levels tend to decrease since the fetus demands glucose as the primary energy source, consuming up to $70 \%$ of the maternal production (Kaneko, Harvey \& Bruss 2008). Low glucose levels at the end of pregnancy should be monitored because hypoglycemic sheep may develop pregnancy toxemia, which can lead to death. However, based on our data and on the reports above, it is possible to observe that pregnant ewes raised under tropical conditions tend to have low levels of blood glucose without showing any sign of pregnancy toxemia. This endorses the importance of determining a suitable reference interval that includes data from animals raised under similar conditions of management, nutrition and location. In addition, it is known that stress factors such as management changes can lead to a severe negative energy balance, triggering ketosis in sheep. The studies mentioned above corroborate our reports that the lower range for blood glucose level in pregnant sheep is lower than that reported by Kaneko, Harvey and Bruss (2008) of $50 \mathrm{mg} / \mathrm{dL}$, reaching $29 \mathrm{mg} / \mathrm{dL}$.

It is known that serum cholesterol metabolisms in pregnant and non-pregnant sheep are markedly distinct (Zywicki et al. 2018). That is because, during ovine gestation, cholesterol is a substrate for steroids; 
first the corpus luteum and then the placenta, and the ovine placenta relies solely on cholesterol for progesterone production. Decreased cholesterol levels may occur in sheep fed low-energy diets, in cases of hyperthyroidism and during prepartum (Santos et al. 2014) or when there is a decrease in ruminal acetate, which is the primary precursor for cholesterol synthesis (Marai et al. 2008). In contrast, Balikci, Yildiz and Gürdoğan (2007) reported that there is a gradual increase in cholesterol levels in sheep at the end of pregnancy due to its reduced responsiveness to insulin, which directly affects the metabolism of adipose tissue during late pregnancy, leading to an increase in the cholesterol and lipoprotein concentrations (Schlumbohm and Harmeyer 1997). The mean serum cholesterol is $22.3 \mathrm{mg} / \mathrm{dL}$ in primiparous Ouled Djellal ewes during early pregnancy (Safsaf et al. 2014) and $26.48 \mathrm{mg} / \mathrm{dL}$ in Iranian fat-tailed Baloochi ewes one day before lambing (Taghipour et al. 2010). On the other hand, Khatun et al. (2011) reported a mean serum cholesterol level of $107.6 \mathrm{mg} / \mathrm{dL}$ in early-pregnant ewes. According to Kandiel, El-Khaiatb and Mahmoud (2016), the blood cholesterol levels in Barki ewes at early (60 d), mid (90 d) and late pregnancy (135 d) were $36.7,36.4$ and $34.4 \mathrm{mg} / \mathrm{dL}$, respectively. Such results are within the range defined in the present study (13$117 \mathrm{mg} / \mathrm{dL}$ ), but do not agree with the physiological values proposed by Kaneko, Harvey and Bruss (2008). In sheep with pregnancy toxemia, Van Saun (2000) reported a mean serum cholesterol level of $59 \mathrm{mg} / \mathrm{dL}$. It is known that there is a trend towards reduction in serum cholesterol levels in animals diagnosed with ketosis, suggesting that the ability of the liver to transport this metabolite in the blood as VLDL may be compromised. Under this circumstance, the liver starts to accumulate fat, contributing to the onset of pregnancy toxemia if associated with body condition scores above 3 (on a 1-5 scale) (Santos et al. 2011).

The maternal lipid metabolism is extensively modified during pregnancy to ensure the maintenance of nutrient supply to the growing fetus (Kandiel, El-Khaiat and Mahmoud 2016), especially when we consider the physiological adaptations of sheep to meet their increased energy demands for gestation. Under this condition, the rate of adipose tissue metabolism is changed, resulting in increased triglyceride metabolisation aimed at obtaining energy and producing steroid hormones such as progesterone (Castillo et al. 1999). Therefore, high serum triglyceride levels may be a result of energy mobilization of adipose tissue, particularly in animals under energy deficit (Oliveira et al. 2014). On the other hand, the number of total insulin receptors reduces with the advancement of pregnancy, which could result in decreased triglyceride concentration because of an inefficient stimulation of lipogenesis by insulin (Yokus et al. 2006). Sheep diagnosed with hyperketonemia also have low serum triglyceride concentration due to the reduced appetite (Santos et al. 2011). In an assay with Makouei sheep seven days before the expected lambing time, Mohammadi, Anassori and Jafari (2016) reported a mean serum triglyceride concentration of $46.54 \mathrm{mg} / \mathrm{dL}$, similar to that found by Castillo et al. (1999) in twin-bearing Assaf ewes 10 days before parturition (45.4 $\mathrm{mg} / \mathrm{dL}$ ). Serum triglyceride concentrations were also above the upper range stated by Kaneko, Harvey and Bruss (2008) in Akkaraman ewes at 150 days of pregnancy (Balikci, Yildiz and Gürdoğan 2007) and Ouled Djellal sheep (Deghnouche et al. 2013) of 32.7 and $34 \mathrm{mg} / \mathrm{dL}$, respectively. These authors observed a mean concentration of $81.24 \mathrm{mg} / \mathrm{dL}$ in Santa Inês sheep at the end of pregnancy. In contrast, Kandiel, El-Khaiat and Mahmoud (2016) reported a mean serum triglyceride concentration of $16.2 \mathrm{mg} / \mathrm{dL}$ in Barki ewes at midpregnancy.

High- and low-density lipoproteins are the primary endogenous sources of cholesterol for steroidogenesis by luteal cells, which is critical for the establishment and maintenance of pregnancy, and they carry most of the circulating cholesterol in the serum of adult animals. Although Kaneko, Harvy and Bruss (2008) did not report HDL and LDL cholesterol concentrations in their study, several research papers corroborate the reference ranges found in the present study for pregnant sheep. The mean HDL and LDL serum concentrations were 18.01 and $13.15 \mathrm{mg} / \mathrm{dL}$ for Tsigai ewes (Antunović et al. 2011) and 12.15 and $32.81 \mathrm{mg} / \mathrm{dL}$ for Santa Inês sheep seven days before lambing (Nasciutti et al. 2012). With the advancement of pregnancy in Barki ewes, the mean HDL concentrations at early, mid and late gestation were 11, 9.7 and $11.2 \mathrm{mg} / \mathrm{dL}$, respectively, whereas the corresponding serum LDL concentrations were 16.919 .5 and 16.7 $\mathrm{mg} / \mathrm{dL}$ (Kandiel, El-Khaiat \& Mahmoud 2016). According to the authors, high HDL concentration in ewes may be evidence of low steroidogenesis during late pregnancy. The diet can also influence the concentrations of HDL and LDL in sheep, since ewes fed low-fat diets tend to have reduced serum levels of both lipoproteins.

Fatty acids are esterified to triglycerides, incorporated into the hepatic tissue and exported from the liver during the synthesis and secretion of hepatic VLDL (Berchielli, Pires and Oliveira 2006). Pregnant sheep 
have a deficiency in the production of VLDL and, under situations of compromised lipid metabolism, triglycerides cannot be removed from hepatocytes, leading to hepatic insufficiency (Dzadzowski et al. 2015). Concurrent low cholesterol levels indicate that the liver's capacity to export fat as VLDL is impaired, triggering the process of fat accumulation in the liver (Grummer 1993). In an assay with Sakiz-Awassi crossbreed sheep, the VLDL concentrations during early and late pregnancy were 4.75 and $3.13 \mathrm{mg} / \mathrm{dL}$, respectively (Yokus et al. 2006), whereas in pregnant Santa Inês hair sheep the concentration was 6.92 $\mathrm{mg} / \mathrm{dL}$. With the advancement of pregnancy in Barki ewes, the mean VLDL concentrations at early, mid and late gestation were 7.0, 7.4 and $6.5 \mathrm{mg} / \mathrm{dL}$, respectively (Kandiel, El-Khaiat and Mahmoud 2016). All the reports above corroborate our range for VLDL in pregnant sheep.

Serum total protein is composed of albumin and globulins and varies according to the physiological status and age of the livestock. Overall, decreases in total protein concentration are observed with the advancement of pregnancy for several reasons: a normal pregnancy-induced haemodilution effect as a result of the increased blood volume and body water content (Zywicki et al. 2018; Swetha et al. 2018), decreases in globulin and immunoglobulin levels when colostrum is being produced in the udder (Balikci, Yildiz and Gürdoğan 2007; Kaneko, Harvey and Bruss 2008) and increased needs for amino acids for fetal muscle development (Castillo et al. 1999; Jainudeen \& Hafez 1994). However, low total protein levels are also associated with an impairment of the usual hepatic functions in sheep diagnosed with pregnancy toxemia (Santos et al. 2011). The serum total protein concentration was $4.22 \mathrm{~g} / \mathrm{dL}$ in Iraqi ewes during the second month of pregnancy (Jodan and Al-Hamedawi 2017). According to Gurgoze et al. (2009) analysing Awassi ewes at the 120th day of pregnancy and Nasciutti et al. (2012) studying Santa Inês hair sheep seven days before lambing, the total protein concentrations were 5.96 and $4.79 \mathrm{~g} / \mathrm{dL}$, respectively. In Karakul sheep at late pregnancy, Baumgartner and Pernthaner (1994) reported a mean value of $6.13 \mathrm{~g} / \mathrm{dL}$. The cited studies agree with our findings that the serum biochemical references for total protein in pregnant sheep are wider than that established by Kaneko, Harvey and Bruss (2008).

Uric acid is converted into ammonia and then used by ruminal microorganisms as a microbial growth factor for the synthesis of microbial protein (Orskov 1982). The serum uric acid concentration usually decreases during early pregnancy due to increased renal clearance of this substance. However, uric acid concentration does not increase during late pregnancy, even with decreased clearance in the renal tubules (Ognik et al. 2015). According to these authors, this outcome is a possible effect of the increased volume of circulating blood. The physiological range for serum uric acid determined in our study was narrower than that stated by Kaneko, Harvey and Bruss (2008). In an assay with ewes of the synthetic SCP line, the serum uric acid levels were 0.36 and $0.61 \mathrm{mg} / \mathrm{dL}$ at 1.5 months of pregnancy and 24 hours before lambing, respectively (Ognik et al. 2015). According to Yarim et al. (2007), the serum concentration of uric was 0.15 $\mathrm{mg} / \mathrm{dL}$ in ewes with a healthy pregnancy and $0.30 \mathrm{mg} / \mathrm{dL}$ in ewes with severe cases of pregnancy toxaemia. High concentrations of uric acid in the serum might be evidence of kidney dysfunction (Ognik et al. 2015).

Serum urea concentration is directly related to dietary protein levels, as well as the protein-energy ratio of the diet (Wittwer et al. 1993). Pregnant ewes have decreased feed intake at the end of gestation, which may lead to increased proteolysis of endogenous amino acids to be used as an energy source, resulting in increased urea concentrations (Feijó et al. 2014). In addition to the decline in feed intake in response to stress during late pregnancy, hormonal alterations during lambing are also associated with decreases in serum urea concentration (Taghipour et al. 2010). On the other hand, some authors hypothesize that the highest serum urea concentration during lambing is due to the decreased glomerular filtration rate and urea clearance (Raoofi et al. 2013; Rodriguez et al. 1996) and high protein metabolism during pregnancy (Gurgoze et al. 2009). In late-pregnancy Santa Inês ewes, Cardoso et al. (2010) reported a mean serum urea concentration of $40.48 \mathrm{mg} / \mathrm{dL}$, whereas Lima et al. (2016) and Morsy et al. (2016) observed means of 45.75 and $49.9 \mathrm{mg} / \mathrm{dL}$, respectively. In Makouei sheep on day seven before the expected lambing time, the mean serum urea concentration observed was $44.6 \mathrm{mg} / \mathrm{dL}$ (Mohammadi, Anassori and Jafari 2016). All the values reported above were within the physiological ranges defined in our study but below the lower limit determined by Kaneko, Harvey and Bruss (2008).

Albumin is considered the most sensitive indicator of the protein nutritional status in the long term, since low concentrations generally indicate inadequate protein intake (Cardoso et al. 2010; Oliveira et al. 2014). Albumin plays a role in carrying non-esterified fatty acids to be used by peripheral tissues as an energy 
source (González and Silva 2006), besides being a significant source of amino acids to supply the demands of the fetus (Jainudeen and Hafez 1994). Even in animals diagnosed with pregnancy toxemia, serum albumin levels remain within the physiological limits for the species, as observed for Santa Ines, Dorper and crossbred sheep, with a mean value of $3.1 \mathrm{~g} / \mathrm{dL}$ (Santos et al. 2011). According to these authors, serum albumin concentrations in animals diagnosed with pregnancy toxemia do not differ from those of healthy sheep at the same period of gestation, and alterations in serum albumin levels are associated with chronic problems or acute changes in the animals' hydration. Contrary to the narrow range determined for serum albumin in the study by Kaneko, Harvey and Bruss (2008), the values from our report are broader, varying from 1.56 to $5.01 \mathrm{~g} / \mathrm{dL}$ in pregnant sheep. The serum albumin concentration of $1.79 \mathrm{~g} / \mathrm{dL}$ in Sakiz-Awassi crossbreed sheep (Yokus et al. 2006) was within the range for the proposed physiological values although approximately $25 \%$ lower than the lower limit determined by Kaneko, Harvey and Bruss (2008). In NARI Suwarna Ewes in India, the serum albumin concentration was $3.67 \mathrm{~g} / \mathrm{dL}$ at the second month of pregnancy (Swetha et al. 2018), whereas it was $3.64 \mathrm{~g} / \mathrm{dL}$ in Awassai ewes at the 145th day of pregnancy (Gurgoze et al. 2009) and $4.91 \mathrm{~g} / \mathrm{dL}$ in Makouei sheep seven days before the expected lambing time (Mohammadi, Anassori and Jafari 2016).

Creatine is produced mainly in the kidneys and liver and then transported to the muscle and brain in the blood, where it is converted to phosphocreatine (Marai et al. 2008). In muscle, approximately 1-2\% of free creatine is converted to creatinine daily (Burtis and Ashwood 1996). Creatinine excretion is primarily modified by the urinary flow velocity, and levels above the physiological values have been observed as the glomerular filtration rate decreases (Ognik et al. 2015). High levels of creatinine may indicate renal failure (Nascimento et al. 2015). For serum creatinine, the values found in the literature are lower than that reported by Kaneko, Harvey and Bruss (2008). Morsy et al. (2016) reported a mean serum creatinine of 0.49 $\mathrm{mg} / \mathrm{dL}$ in late-pregnant Santa Inês ewes in Brazil, whereas it was $0.50 \mathrm{mg} / \mathrm{dL}$ in Awassi ewes of 21 days of pregnancy (Gurgoze et al. 2009). In an assay with Sakiz-Awassi crossbreed sheep in early and late pregnancy, the serum creatinine levels were 0.84 and $0.65 \mathrm{mg} / \mathrm{dL}$, respectively (Yokus et al. 2006). The values were higher in Santa Inês hair sheep at late gestation (Nascimento et al. 2015) reaching $0.95 \mathrm{mg} / \mathrm{dL}$, but still within limits determined by our study. However, for sheep diagnosed with pregnancy toxemia, Santos et al. (2011) reported a mean serum creatinine concentration of $2.01 \mathrm{mg} / \mathrm{dL}$.

Aspartate aminotransferase (AST) is a liver enzyme involved in the process of transamination, yielding oxaloacetate as the end product of metabolism (Dzadzowski et al. 2015). This enzyme is found in hepatocytes, red blood cells and muscles (Al-Hadithy, Badawi and Mahmood 2013), and its serum levels are used to estimate liver function, since increased AST levels are associated with liver fatty infiltration (Lubojacka et al. 2005). The serum AST has a positive correlation with milk yield, physical activity and heart problems (Feijó et al. 2014; Antunović, Šperanda and Steiner 2004). Despite the physiological ranges determined in this study for serum aspartate aminotransferase in pregnant sheep were similar to those of Kaneko, Harvey and Bruss (2008), some studies reported values more like the interval found in this work. Nascimento et al. (2015) observed a serum aspartate aminotransferase level of 53.7 U/L in Santa Inês sheep three weeks before lambing, and Yokus et al. (2006) reported a mean of $46.23 \mathrm{U} / \mathrm{L}$ in Sakiz-Awassi crossbreed sheep during early pregnancy. In Merino landschaf pregnant ewes on the 20th day before lambing, the serum AST concentration was $104.87 \mathrm{U} / \mathrm{L}$ ), whereas it was $97.20 \mathrm{U} / \mathrm{L}$ in Tsigai ewes (Antunović et al. 2011).

Gamma-glutamyl transferase is a liver enzyme found exclusively in hepatocytes and considered a biomarker of liver injury (Copeland 2000). The GGT and AST activity should be taken into consideration together, since both can indicate an injury to the liver tissue. The GGT levels may increase immediately if there is an acute hepatic injury due to the release of membrane fragments containing the enzyme (Thrall et al. 2007). Data found in the literature for GGT exceed the upper limit recommended by Kaneko, Harvey and Bruss (2008), which ranges from 20 to $52 \mathrm{U} / \mathrm{L}$. This result may be related to the fact that their data do not consider the category and physiological status of the animal. The serum GGT concentration in Sakiz-Awassi crossbreed sheep during late pregnancy was $54.84 \mathrm{U} / \mathrm{L}$ (Yokus et al. 2006), a value still lower than that observed by Zywicki et al. (2018) in crossbreed Western-breed ewes during the third-trimester pregnancy, which reached up to $76 \mathrm{U} / \mathrm{L}$. In Lacaune ewes with a healthy pregnancy, with subclinical ketosis and with clinical ketosis, the GGT activities averaged 28.4, 65.9 and $65.1 \mathrm{U} / \mathrm{L}$, respectively (Marutsova 2015). Santos et al. (2011) reported an average GGT level of 83.4 U/L in Santa Inês, Dorper and crossbred ewes diagnosed with pregnancy toxemia after their discharge. 
Alkaline phosphatase (ALP) is an intrahepatic enzyme found mainly in the biliary ducts and placenta (Al-Hadithy, Badawi and Mahmood 2013) and its serum concentrations are considered valuable parameters for the diagnosis of ketosis in sheep (Sargison et al. 1994). In an assay with Chios sheep that manifested clinical signs of pregnancy toxaemia, the ALP concentration reached 196.55 U/L (Dzadzovski et al. 2015). Studying white-faced Western-breed ewes at late gestation, Zywicki et al. (2018) reported a minimum serum ALP concentration of $36 \mathrm{U} / \mathrm{L}$, whereas Yokus et al. (2006) observed an average value of $59 \mathrm{U} / \mathrm{L}$ in Sakiz-Awassi crossbreed sheep during early pregnancy. In Mehraban ewes 10 days before expected lambing, the values for ALP were slightly higher, reaching $166.3 \mathrm{U} / \mathrm{L}$ (Aliarabi et al. 2018). Ewes diagnosed with pregnancy toxaemia with high ALP activity recovered more slowly compared with those with lower ALP serum levels (Marutsova et al. 2015).

\section{Conclusions}

The serum biochemical reference ranges for pregnant sheep determined in our study are strongly divergent from those established by one of the most cited books on the topic, especially considering the high serum urea and cholesterol concentrations and low levels of blood glucose observed. Therefore, it is essential to consider the physiological status when evaluating the blood metabolic profile of pregnant ewes in order to maintain an adequate nutritional management and to prevent health disorders that may lead to productive and reproductive losses.

Authors' Contributions: VARANIS, L.F.M.: acquisition of data, analysis and interpretation of data, drafting the article; OLIVEIRA, K.A.: drafting the article; ARAÚJO, C.M.: drafting the article; CRUZ, W.F.G.: drafting the article; MACEDO JÚNIOR, G.L.: acquisition of data, analysis and interpretation of data, drafting the article. All authors have read and approved the final version of the manuscript.

Conflicts of Interest: The authors declare no conflicts of interest.

Ethics Approval: Not applicable.

Acknowledgments: Not applicable.

\section{References}

AL-HADITHY, H.A.H., BADAWI, N.M. and MAHMOOD, M.M. Estimation of Serum Liver Enzymes Activities in Awassi Sheep. The Iraqi Journal of Veterinary Medicine. 2013, 37(1), 115-120.

ALIARABI, H., FADAYIFAR, A., ALIMOHAMADY, R. and DEZFOULIAN, A.H. The effect of maternal supplementation of zinc, selenium, and cobalt as slow-release ruminal bolus in late pregnancy on some blood metabolites and performance of ewes and their lambs. Biological Trace Element Research. 2018, 187(2), 403-410. https://doi.org/10.1007/s12011-018-1409-8

ANTUNOVIĆ, Z., ŠPERANDA, M. and STEINER, Z. The influence of age and the reproductive status to the blood indicators of the ewes. Archives Animal Breeding. 2004, 47(3), 265-273. https://doi.org/10.5194/aab-47-265-2004

ANTUNOVIC, Z., et al. Blood metabolic profile and some of hormones concentration in ewes during different physiological status. Bulgarian Journal of Agricultural Science. 2011, 17(5), 687-695.

BALIKCI, E., YILDIZ, A. and GÜRDOĞAN, F. Blood metabolite concentrations during pregnancy and postpartum in Akkaraman ewes. Small Ruminant Research. 2007, 67(2-3), 247-251. https://doi.org/10.1016/i.smallrumres.2005.10.011

BAUMGARTNER, W. and PERNTHANER, A. Influence of age, season, and pregnancy upon blood parameters in Austrian Karakul sheep. Small Ruminant Research. 1994, 13(2), 147-151. https://doi.org/10.1016/0921-4488(94)90090-6

BELL, A.W. Regulation of organic nutrient metabolism during transition from late pregnancy to early lactation. Journal of Animal Science. 1995, 73, 2804-2819.

BERCHIELLI, T.T., PIRES, A.V. and OLIVEIRA, S.G. Nutrição de ruminantes. 1st ed. Jaboticabal: Funep, 2006.

BOBE, G., YOUNG, J.W. and BEITZ, D.C. Pathology, etiology, prevention, treatment of fatty liver in dairy cows. Journal of Dairy Science. 2004, 87, 3105-3124. https://doi.org/10.3168/jds.S0022-0302(04)73446-3

BURTIS, C.A. and ASHWOOD, E.R. Tietz Textbook of Clinical Chemistry. 3rd ed. Philadelphia: W.B. Saunders, 1999.

CARDOSO, E.C., et al. Peso e condição corporal, contagem de OPG e perfil metabólico sanguíneo de ovelhas da raça Santa Inês no periparto, criadas na região da Baixada Litorânea do Estado do Rio de Janeiro. Revista Brasileira de Ciência Veterinária. 2010, 17(2), 77-82.

CASTILLO, C., et al. Effect of physiological stage and nutritional management on some serum metabolite concentrations in Assaf ovine breed. Archives Animal Breeding. 1999, 42(4), 377-386. https://doi.org/10.5194/aab-42-377-1999 
COPELAND, R.A. Enzymes:A Practical Introduction to Structure, Mechanism and Data Analysis. 2nd ed. New York: Wiley-VCH, 2000.

DEGHNOUCHE, K., TLIDJANE, M., MEZIANE, T., and TOUABTI, A. Influence of physiological stage and parity on energy, nitrogen and mineral metabolism parameters in the Ouled Djellal sheep in the Algerian Southeast arid area. African Journal of Agricultural Research. 2013, 8(18), 1920-1924. https://doi.org/10.5897/AJAR09.576

DZADZOVSKI, I., et al. Influence of the Season on the Metabolic Profile in Chios Sheep. Macedonian Veterinary Review. 2015, 38(2), 183-188. https://doi.org/10.14432/j.macvetrev.2015.06.048

FEIJÓ, J.O., et al. Avaliação de parâmetros bioquímicos clínicos de ovelhas do grupo genético pantaneiro gestantes e não gestantes. Brazilian Journal of Veterinary Research and Animal Science. 2014, 51(2), 111-117. https://doi.org/10.11606/issn.2318-3659.v51i2p111-117

FRIEDEWALD, W.T., LEW, R. I. and FREDRICKSON, D.S. Estimation of the concentration of low-density lipoprotein cholesterol in plasma, without the use of the preparative ultracentrifuge. Clinical Chemistry. 1972, 18, 499-502.

GONZÁLEZ, F.H.D. and SILVA, S.C. Introdução a bioquímica clínica veterinária. 2 ed. Porto Alegre: Editora da UFGRS, 2006.

GRUMMER, R.R. Etiology of lipid-related metabolic disorders in periparturient dairy cows. Journal of Dairy Science. 1993, 76, $3882-3896$.

GÜRGÖZE, S.Y., ZONTURLU, A.K., ÖZYURTLU, N., and IÇEN, H. Investigation of Some Biochemical Parameters and Mineral Substance During Pregnancy and Postpartum Period in Awassi Ewes. Kafkas Universitesi Veteriner Fakultesi Dergisi. 2009, 15(6), 957-963.

https://doi.org/10.9775/kvfd.2009.858

HAFFAF, S. and BENALLOU, B. Changes in energetic profile of pregnant ewes in relation with the composition of the fetal fluids. Asian Pacific Journal of Tropical Biomedicine. 2016, 6(3), 256-258. https://doi.org/10.1016/j.apjtb.2015.11.005

HU, G., MCCUTCHEON, S.N., PARKER, W.J. and WALSH, P.A. Blood metabolite levels in late pregnant ewes as indicators of their nutritional status. New Zealand Journal of Agricultural Research. 1990, 33(1), 63-68. https://doi.org/10.1080/00288233.1990.10430661

JAINUDEE, M.R. and HAFEZ, E.S.E. 1994. Gestation, prenatal physiology and parturition. In: HAFEZ, E.S.E. (Ed). Reproduction in farm animals. Philadelphia: Lea and Febiger.pp. 247-283.

JODAN, W.M. and AL-HAMEDAWI, T.M. Gestational variations in the metabolites of the fetal amniotic fluid and maternal blood serum in Iraqi ewes at different stages of pregnancy. Journal For Veterinary Medical Sciences. 2017, 8(1).

KANDIEL, M., EL-KHAIAT, H. and MAHMOUD, K. Changes in some hematobiochemical and hormonal profile in Barki sheep with various reproductive statuses. Small Ruminant Research. 2016, 136, 87-95. http://dx.doi.org/10.1016/j.smallrumres.2016.01.011

KANEKO, J.J., HARVEY, J.W. and BRUSS, M.L. Clinical Biochemistry of Domestic Animals. 6th ed. San Diego: Academic Press, 2008.

KHATUN, A., et al. Biochemical indices in sheep during different stages of pregnancy. Asian Journal of Animal and Veterinary Advances. 2011, 6, 175-181. https://dx.doi.org/10.3923/ajava.2011.175.181

LIMA, E.H.F., et al. Efeito da monensina sódica sobre o perfil metabólico de ovelhas antes e após o parto. Ciência Animal Brasileira. 2016, 17(1), 105-118. https://doi.org/10.1590/1089-6891v17i128370

LUBOJACKA, V., et al. Liver steatosis following supplementation with fat in dairy cows' diets. Acta Veterinaria Brno. 2005, 74, 217-224.

MARAI, I.F.M., EL-DARAWANY, A.A., FADIEL, A., and ABDEL-HAFEZ, M.A.M. Reproductive performance traits as affected by heat stress and its alleviation in sheep. Tropical and Subtropical Agroecosystems. 2008, 8(3), 209-234.

MARUTSOVA, V. Changes in blood enzyme activities in ewes with ketosis. International Journal of Advanced Research. 2015, 3(6), 462-473.

MOHAMMADI, V., ANASSORI, E. and JAFARI, S. Measure of energy related biochemical metabolites changes during peri-partum period in Makouei breed sheep. Veterinary Research Forum. 2016, 7(1), 35-39.

MORSY, A.S., et al. Impact of Brazilian red propolis extract on blood metabolites, milk production, and lamb performance of Santa Inês ewes. Tropical Animal Health and Production. 2016, 48(5), 1043-1050. https://doi.org/10.1007/s11250-016-1054-1

NASCIMENTO, P.M., et al. Metabolismo oxidativo e perfil bioquímico de ovelhas santa Inês no período periparto: efeito da suplementação parenteral com vitamina E. Semina: Ciências Agrárias. 2015, 36(3), 1397-1408. https://doi.org/10.5433/1679-0359.2015v36n3p1397

NASCIUTTI, N., et al. Perfil metabólico em ovelhas Santa Inês, com baixo escore de condição corporal, no periparto. Boletim De Indústria Animal. 2012, 69(2), 137-145.

OGNIK, K., PATKOWSKI, K., GRUSZECKI, T., and KOSTRO, K. Redox status in the blood of ewes

in the perinatal period and during lactation. Bulletin of the Veterinary Institute in Pulawy. 2015, 59(4), 557-562. https://doi.org/10.1515/bvip2015-0083

OLIVEIRA, R.P.M., MADURO, A.H.P., LIMA, E.S., and OLIVEIRA, F.F. Perfil metabólico de ovelhas Santa Inês em diferentes fases de gestação criadas em sistema semi-intensivo no Estado do Amazonas. Ciência Animal Brasileira. 2014, 15(1), 81-86.

https://doi.org/10.5216/cab.v15i1.15720

ORSKOV, E.R. Protein nutrition in ruminants. London: Academic, 1982. 
RAOOFI, A., JAFARIAN, M., SAFI, S., and VATANKHAH, M. Fluctuations in energy-related metabolites during the peri-parturition period in LoriBakhtiari ewes. Small Ruminant Research.2013, 109(1), 64-68. https://doi.org/10.1016/j.smallrumres.2012.06.012

RODRIGUEZ, M.N., et al. Renal functions and urea handling in pregnant and lactating Corriedale ewes. Canadian Journal of Animal Science. $1996,76,469-472$.

ROOK, J.S. Pregnancy toxemia of ewes, does, and beef cows. Veterinary Clinics of North America: Food Animal Practice. 2000, 16(2), $293-317$. https://doi.org/10.1016/S0749-0720(15)30107-9

SAFSAF, B., et al. Effect of Age and Physiological Status on Some Serum Energy Metabolites and Progesterone in Ouled Djellal Breed Ewes in Algeria. International Journal of Animal and Veterinary Sciences. 2014, 8(12), 1204-1209.

SANTOS, F.C.O., et al. Indicadores bioquímicos e hormonais de casos naturais em toxemia da prenhez em ovelhas. Pesquisa Veterinária Brasileira. 2011, 31(11), 974-980. https://doi.org/10.1590/50100-736X2011001100006

SANTOS, F.M.S.C., et al. Perfil bioquímico em ovelhas da raça Morada Nova nos períodos de gestação, parto e pós-parto. Ciência veterinária nos trópicos. 2014, 17(1-2), 24-29.

SARGISON, N.D., et al. Plasma enzymes and metabolites as potential prognostic indices of ovine pregnancy toxemia - a preliminary study. British Veterinary Journal. 1994, 150, 271-277.

SCHLUMBOHM, C., and HARMEYER, J. Hypocalcemia reduces endogenous glucose production in hyperketonemic sheep. Journal Dairy Science. 2003, 86(6), 1953-1962. https://doi.org/10.3168/jds.S0022-0302(03)73783-7

SOLBERG, H.E. RefVal 4.11 software user's guide. RefVal, Rykkinn, Norway, 2006.

SWETHA, H.S., et al. Serum Biochemical Components in NARI Suwarna Ewes at Different Stages of Pregnancy. International Journal of Livestock Research. 2018, 8(5), 232-237. https://doi.org/10.5455/ijlr.20171027090517

TAGHIPOUR, B., et al. Variations of Energy Related Biochemical Metabolites During Periparturition Period in Fat-Tailed Baloochi Breed Sheep. Iranian Journal of Veterinary Science and Technology. 2010, 2(2), 85-92. https://doi.org/10.22067/veterinary.v2i2.8368

THRALL, M.A., et al. Avaliação laboratorial do fígado. In: Hematologia e bioquímica veterinária. São Paulo: Roca, 2007.

VAN SAUN, R. Pregnancy toxemia in a flock of sheep. Journal of the American Veterinary Medical Association. 2000, 217(10), $1536-1539$. https://doi.org/10.2460/javma.2000.217.1536

WITTWER, F., HEUER, G., CONTRERAS, P.A. and BHÖMWALD, T.M. Valores bioquimicos clínicos sanguíneos de vacas cursando com decúbito em el sur de Chile. Archivos de Medicina Veterinária. 1993, 15, 83-88.

YARIM, G., KARAHAN, S. and NISBET, C. Elevated Plasma Levels of Interleukin 1 $\beta$, Tumour Necrosis Factor $\alpha$ and Monocyte Chemotactic Protein 1 Are Associated with Pregnancy Toxaemia in Ewes. Veterinary Research Communications. 2007, 31(5), 565-573.

https://doi.org/10.1007/s11259-007-3551-1

YOKUS, B., et al. Effects of Seasonal and Physiological Variations on the Serum Chemistry, Vitamins and Thyroid Hormone Concentrations in Sheep. Journal of Veterinary Medicine Series A. 2006, 53(6), 271-276. https://doi.org/10.1111/j.1439-0442.2006.00831.x

ZYWICKI, M.E., et al. Impact of the ovarian cycle and pregnancy on plasma chemistry values in ewes. Journal of Veterinary Diagnostic Investigation. 2018, 30(2), 238-244. https://doi.org/10.1177/1040638717752217.

Received: 1 April 2020 | Accepted: 13 May 2020 | Published: 2 July 2021

This is an Open Access article distributed under the terms of the Creative Commons Attribution License, which permits unrestricted use, distribution, and reproduction in any medium, provided the original work is properly cited. 